\title{
Cowbird Capers
}

\author{
Arthur Ward, Director S.N.H.S.
}

\author{
pirector S.N.H.S.
}

Pausing at the corner of the house, I heard a slight thud on the lawn as though a Robin's egg had fallen from the high tree. Walking over to investigate I could not see anything. On turning away there was another thud and looking down I saw a newly fledged Yellow Warbler and then I saw also the one that had fallen first. This was repeated twice more. On looking up into the tall poplar tree I observed the Warbler's nest, made of Cottenwood fluff, 35 feet up on a slender branch. What was the cause of all this!

At this moment Harold Baldwin, Swift Current's Leader Post representative, came along and we discussed the little tragedies that most birds are subject to. Here we surmised that our brave little Warblers had again fallen victims to the designing Cowbird.

The shock of falling from that height was too much, for two of the little ones were dead; the other two seemed lively. It was too high and far out on the branch to replace them. Had it been a lilac bush this easily could have been done. But what of the young Cowbird? It would seem that it had tossed overboard the rightful occupants.

I watched the nest for three days and observed the parent iVarblers flying to the nest, then later I noticed that the nest had fallen also. It was not the neat deep little nest but rather flattened out. No young Cowbird was visible. I was just about ready to leave for the farm, so took along the two young fledglings, intending to place them with other parents. I had a nest in mind. Previously I had observed a Ked-winged Blackbird's nest containing eggs, and also a groggy-eyed young Cowbird. My intention was to turn out the Cowbird and repalce it with the Warblers. But I found the Cowbird dead. Anyhow I put the two young Warblers in, thinking that adoption might again prevail. I waited until dark to see if the parents were covering them, but found them its stay with us during the summer is the noticable and resentful. This case would resemble that of the English Cuckoo. The female Cowbird, in our experience, ejects the other eggs, different from the procedure of the parent Cuckoo which takes out one egg and leaves the young Cuckoo to dispose of the rest. With the aid of a natural hollow in its back, and still blind, it heaves the others overboard. Artifical objects, such as pebbles etc. placed there, receive the same treatment. The favourable dupes of the Cuckoo seem to be Wagtails, Hedge Sparrows and Sedge Warblers.

Neither the parent English Cuckoo nor the Cowbird know their young. The parent Cuckoos are away to Africa before the young are able to take care of themselves, but they get there eventually. The young Cowbird, having graduated to the fully fledged is absorbed into the flocks of the Blackbirds that gather in the fall. cold and neglected. So I took them back home and tried to hand feed them, but at this stage they need the parent's saliva. They soon died.

Of the known 276 species parasitized, the Yellow Warbler, owing to 